Growth and Change

Vol. 37 No. 2 (June 2006), pp. 230-254

\title{
The Dynamic Firm-Territory Nexus of Taiwanese Informatics Industry Investments in China
}

\author{
JINN-YUH HSU
}

\begin{abstract}
This article explores the transformation of industrial systems in transborder investments made by Taiwanese information technology investors in China. It asks how crossborder firms would operate in these new territories. The study found that, by and large, Taiwanese investors chose to respond strategically to the tensions in different ways at different stages. At first, regarding China as a land of cheap labor and land, they relocated the Taiwanese industrial system in such a way as to avoid disturbing the hosting regions. The situation changed as China's market emerged confidently and opened gradually to foreign investors after the mid-1990s. Exploring this huge new market in China provided a mandate for Taiwanese investors to prosper. They opened up their firm boundaries and added new departments of research, development, and marketing. They developed from being merely export subcontractors to producing their own brand-name goods. In the most recent stage, Taiwanese investors have created networks to tap into local resources to support new activities. Echoing Yeung (2005) in a recent issue of this journal, this article argues that new investments change the developmental trajectories of the host regions and, at the same time, the regions imbued the incoming firms with their own regional stamp. From this perspective, location and localization decisions by cross-strait firms may be regarded as geographically sensitive strategies whereby firms, as reflexive agents, protect and reinforce their competence through the evolution of a firm-territory nexus.
\end{abstract}

\section{Introduction}

B y the mid-1990s, a decade after Taiwanese small- and medium-sized enterprises (SMEs) first went to China, the majority of cross-strait investments shifted from traditional sectors, such as garments and footwear, to informatics industries, particularly personal computer (PC) components and peripherals. An acute labor shortage and relatively high costs triggered this emigration of Taiwanese high-technology industries, starting from

Jinn-yuh Hsu is an associate professor in the Department of Geography at National Taiwan University, Taipei, Taiwan. His e-mail address is: jinnyuh@ntu.edu.tw.Funding for this research was received from the National Science Council in Taiwan (NSC-94-2415-H-002-026-SSS) and the Program for Globalization Studies of the Institute for Advanced Studies in Humanities and Social Sciences at NTU. The author thanks three referees for their constructive comments, which led to significant improvement of this article. The usual disclaimers apply.

Submitted September 2005; revised July 2005 and November 2005; accepted December 2005.

(C) 2006 Blackwell Publishing, 350 Main Street, Malden MA 02148 US and 9600 Garsington Road, Oxford OX4, 2DQ, UK. 
the most labor-intensive and price-sensitive keyboards and mice to power supply units, and then to motherboards and monitors. ${ }^{1}$ In undertaking cross-strait investments, a series of governance and coordination issues were posed for Taiwanese firms. The first of these is related to the location of the new plant. As Figure 1 demonstrates, most Taiwanese personal computer firms initially chose the Pearl River Delta (PRD) and the Yangtze River Delta (YRD) as their destinations; in fact, the site of many Taiwanese investments have shifted from the former to the latter since 1997, once China's membership into the World Trade Organization (WTO) was assured.

The gathering of overseas Chinese foreign direct investment (FDI) in China has been fully explained (Hsing 1998; Lin 1997; Smart 1998; Wang 2000). According to the Ministry of Foreign Trade and Economic Cooperation (1999), from 1979-1998, the sources of FDI in China concentrated highly in the Great China Circle, including Hong Kong, Taiwan, and Singapore. In total, they accounted for over 70 percent of the total FDI in China. At the same time, most of these ethnic investments went to the culturally and geographically proximate open-door regions such as Guandong and Fujian.

After 1997, YRD, particularly the region spanning from Shanghai to Suzhou (see Figure 2), was assessed as a better location as the market center than its counterpart in South China. Accordingly, it made sense for new firms to create a presence in the area. In addition, the role of the international procurement offices (IPOs) of the key PC buyers, such as Dell, IBM, and Compaq, is critical in organizing the spatial division of labor for the PC production chains. ${ }^{2}$ It is recounted that major Taiwanese PC motherboard and notebook producers rushed to cluster in the YRD (Zhuang, Chen, and Chen 2001). The regional trend reflects the macro policy preference of the central government for a shift from the PRD in the late 1970s to the YRD in the early 1990s (Walcott 2003).

As Yeung (2005) clearly points out, economic geographers should be ever sensitive to the different geographical configurations of firm-specific interactions and practices. The case of networking in the regionalization of Taiwanese information technology (IT) industry investments in China can be used to illustrate this point. In fact, the regionalization process of these firms could be conceived as one of firm-territory decoupling and recoupling (Jessop 2000). It is understood as being embedded in multiple and overlapping processes, linking intra- and interorganizational networks and occurring in different spatial and temporal contexts. ${ }^{3}$ Attention should thus focus on how the firms respond strategically to the divergent institutional environment, and the corresponding organizational reshuffling (Depner and Bathelt 2005; Taylor and Asheim 2001; Yeung 2005).

In light of the organizational perspective of firms, this research aims to explore the changing organizations of Taiwanese IT investors in China. A number of vital concerns will be tackled including the following:

How exactly did the organizational reshuffling process happen as the Taiwanese investors met the Chinese contexts?

How did Taiwanese investors exploit the diversity between the regional institutional environments to handle the uncertainties and opportunities in their Chinese operation? 


\begin{tabular}{|r|r|r|r|}
\hline \multicolumn{1}{|l|}{ Year } & \multicolumn{1}{|l|}{$\begin{array}{l}\text { Pearl River } \\
\text { Delta }\end{array}$} & \multicolumn{1}{l|}{$\begin{array}{l}\text { Yangtze river } \\
\text { Delta }\end{array}$} & The rest \\
\hline 1999 & 559,551 & 528,719 & 75,696 \\
\hline 2000 & $1,120,936$ & $1,279,462$ & 107,875 \\
\hline 2001 & 910,697 & $1,475,149$ & 14,448 \\
\hline 2002 & $2,399,389$ & $3,256,040$ & 352,578 \\
\hline 2003 & $2,601,939$ & $3,782,115$ & 386,450 \\
\hline
\end{tabular}

Units in thousand U.S. dollars

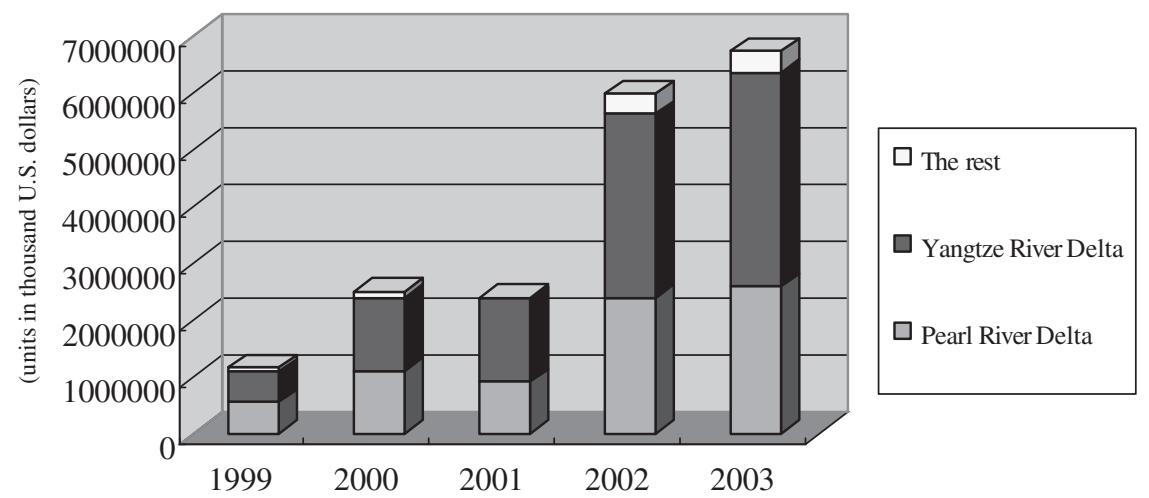

Figure 1. The Geographical Patterns of taiwanese Electronics CrossSTRAIT INVESTMENT IN 1990s.

Source: Statistical reports of cross-strait investments, the Investment Commission of the Ministry of Economic Affairs, various years.

How did the divergent institutional mechanisms work for the transformation of crossborder production systems?

How would one accredit them appropriately?

In the following section, a theoretical review of the firm-territory relationship will be proposed. Then, the methodological approach of the study will be described before the presentation of the empirical findings regarding the changing organization of cross-strait 


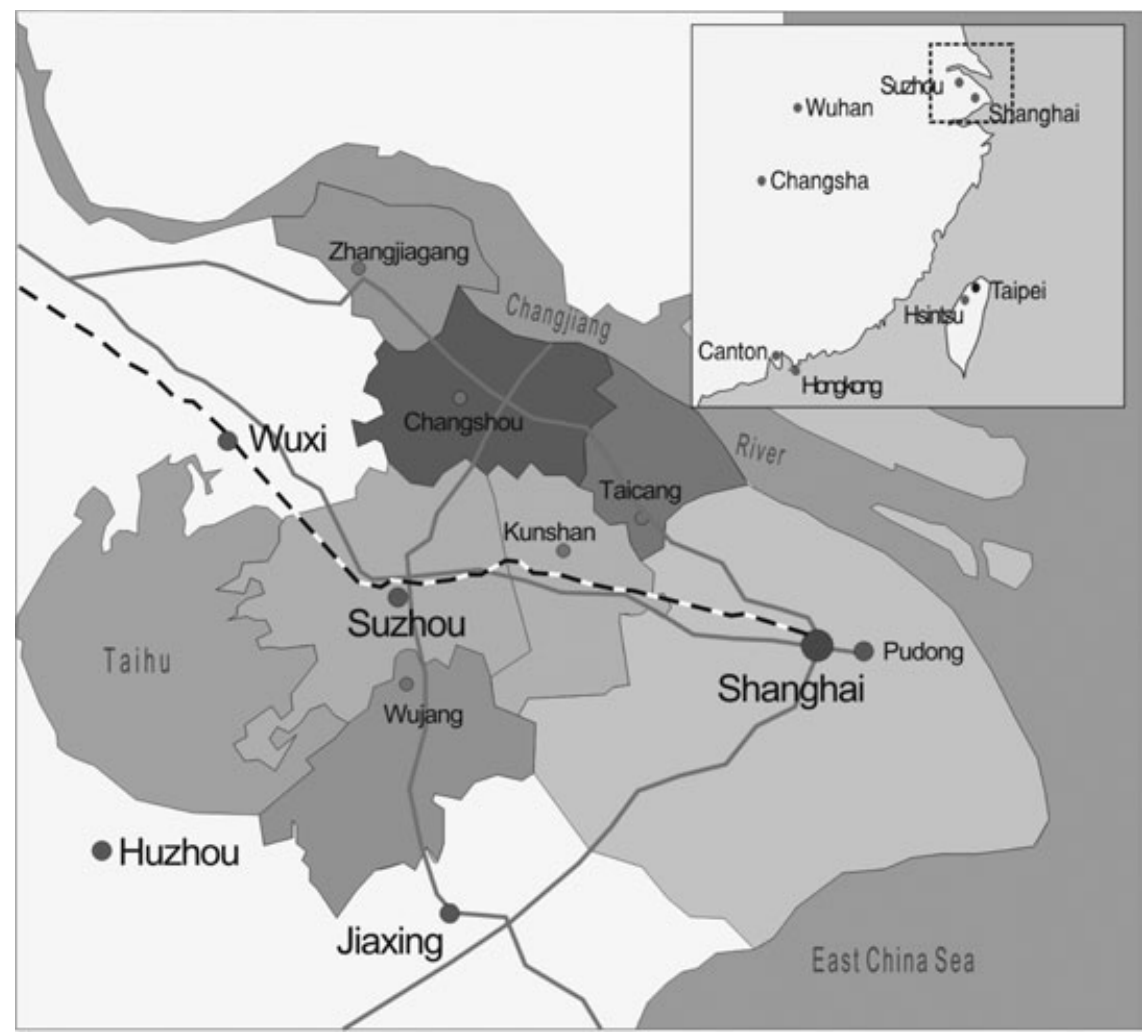

Figure 2. The Location of TAIWANESe InVEstment in the YANGtZe River Delta.

investment. The discussion will consider the changes to the multiple governance mechanisms at various levels, including labor regimes, material input control, inter-firm subcontracting, and the reorganization of cross-border production chains. Finally, the article will conclude with a reflection on the interaction between learning firms and learning regions.

\section{Theoretical Context: Reflexive Firms and Learning Regions}

In the globalizing economy, cross-border business networks are increasingly important and constitute the channels of capital, technology, people, and information flow, and thus usually create social and economic impacts on both home and host countries and regions. A key question to consider is whether the practices of transnational production change or are changed in response to host country industrial environments and regulatory systems. These practices include those both internal and external to the firm. The former refers to 


\section{GROWTH AND CHANGE, JUNE 2006}

the production systems, employment relations, and interdivisional relationships, while the latter covers inter-firm and firm-government relationships.

Understanding the ways in which firms behave and perform in certain territories, or the patterns of firm-territory nexus, has become a key issue in the study of economic geography and revolves around the appropriate theorization of the firm in economic geography (Taylor and Asheim 2001). It has been widely recognized that firms should not be conceived just as legally bounded entities and owners of property assets, but also as institutions with permeable and highly blurred boundaries, or in Dicken and Malmberg's (2001) term, "networks within networks." In the networking process, the firms open up their boundaries, tap into surrounding networks, and create certain realms of firm-territory interaction. Dicken (2000) even dubbed the nexus as the process of "placing firms and firming places," and Schoenberger (1999) called it "firm in region and region in firm." Most of the literature assumes that the hybridization of firm and geographical organizations would occur naturally once the intra-firm networks were grafted onto the inter-firm and firm-space ones (Hollingsworth 1998).

Following Dicken and Malmberg (2001), the firm-territory nexus is mediated by the governance of the territorial industrial systems. Industrial systems vary in accordance with standing conventions that legitimate the exploitation modes of resources and constraints (Saxenian 1994; Storper 1997). The industrial system defines the inter-firm relations and the corresponding governance mechanisms. It is well noted that the key to the competitiveness of Taiwan's IT industry comes not from the individual innovative firm itself but from the collective capabilities of the industrial system of SMEs (Berger and Lester 2005). The different industrial systems lead to the divergent strategies employed by the different firms and the divergent levels of "spatial stickiness" (Saxenian 1994).

After investigating the literature on the convergence of production systems in the global economy, Gertler (2001) concluded that the final consequence will depend on the degree of similarity with the institutional environment of firms and their host regions. In fact, firms take interest not only in matching the institutional similarity to exploit their existing competence, but also in sensing differences in order to explore new trajectories of development (Sabel 1995). In the dynamic change of firm-territory interplay, strategically selfreflexive agents should be taken as the active performers of decision making. Such a view of firms' behavior is different from both the image of the neoclassic rational calculator or the creature of path-dependent routines. It promotes an idea of learning by monitoring intelligently the agents themselves, their situations, the anticipated effects of their actions, and the institutional differences in the regions, and making adjustments to take advantage of emerging opportunities. In contrast to the complete rationality of neoclassical theories, reflexive firms are not regarded as having code books at hand with which they can determine the meaning of the signals from their environing institutions.

Against such understandings, three themes are important in considering the changing firm-territory nexus in the cross-border investment. First, it has to take account of the divergent firm strategies in different time-space bundles. As demonstrated by Schoenberger (1997), firms may exploit different strategies, particularly spatial and organizational 
decoupling and recoupling, in the governance of the industrial system. Firms may take different degrees of territorial linkages with their hosting regions in different periods of economic activities, and may take advantage of the latter in accordance with their evolving competences in mobilizing the local resources. As Boyer (1998) argued, a multiplicity of transformations occurs when the transplants attempt to apply the same principles to spaces that are divergent and heterogeneous in terms of natural resources, economic organization, skill competence, governing regime, and market formation.

Second, as recent research studies of new regionalism have shown, the region should not be taken as a passive container for social actions but rather as an indispensable dimension in which local actors, particularly government institutions, are structured as they arrange their relationships with the global (or nonlocal) level (Amin 2002; Governa and Salone 2004; Swyngedouw 1997). Regions and their embodied institutions possibly behave as a collective actor in the mobilization of resources at various scales and flexibly meet the challenges in the era of spatial competition (Sheppard 2000). In other words, as reflexive as firms, regions can be learning agents in the firm-region nexus.

Third, firms and regions should be regarded as agents with learning and innovative capabilities in the internationalization process (Eriksson, Majkgard, and Sharma 1997). Internationalization is a matter of learning about foreign markets, cultures, and institutions, as well as internal resources and capabilities of the firm. Firms accumulate their knowledge about the hosting institutions and act strategically to buffer themselves from local disturbances to exploit their competence or mobilize local resources to explore new business models. By the same token, regions are able to adjust themselves in the spatial competition and induce foreign investors to become dependent on local territories or relocate to other places. Building on collective assets, regions may adopt different institutional arrangements to bargain with inward investments in spite of the possibilities of institutional lock-in in some cases. These learning regions are regions of institutional innovation to cope with the evolution of different production worlds (Storper 1997). The regional institutional system is not fixed because it can engage in a policy learning process to adapt to new conditions. Regions can adopt solutions that are already successfully applied in other regions, or adjust imported solutions to the specific problems (Benz and Fürst 2002). The different regional institutions allow divergent strategic models for handling new investments.

The article investigates the interaction between firms and their host regions by using a case study of the cross-strait investments by Taiwanese informatics industrial firms. The choice of IT industries is based on the observation that, since the early 1990s, IT has become one of the most strategically important cross-strait investment sectors. Moreover, most of the research on cross-strait investments, such as that by Hsing (1998) and Wu (1997), so far has concentrated on the traditional sectors, such as shoes, garments, and toys. This study will update the theoretical understanding and empirical findings. Finally, while most accounts of cross-strait investments are based on case studies conducted in the PRD (Cheng 1999; Hsing 1998; Wu 1997), this article hopes to provide a preliminary comparison of firm behavior in divergent institutional contexts and vice versa. 


\section{Methodology}

This research is based on about forty interviews with Taiwanese IT sector (including PC component, peripherals, and system house) investors, managers, and two local government agencies. The respondents were interviewed in five field trips conducted from early 2002 to mid-2003. The selection of firms was based on databases published by key investment consulting companies such as the Capital Group (2001) and on a special issue by the noted Taiwanese technology business journal publisher, Business Next (2000), which was widely believed to keep more accurate data on the "real" investments made by Taiwanese high-technology firms. ${ }^{4}$ Accordingly, six key PC system firms were identified as relatively large in investment amount and in attracting subcontractors to follow them in their cross-strait activities. All the targeted firms were on the top fifty list of Taiwanese electronics firms. ${ }^{5}$ In the course of the interviews, the subcontractors for the leading firms were added to the interview list so that the final number of firms came to thirty-nine. The company profiles of the firms interviewed are shown in Table 1.

At the start of the research, a temporary hypothesis about the evolution of the interaction between the investor's production organizations and the local institutions based on theoretical review was proposed. Under this framework, a semistructured set of questions was developed for interviews, which focused on the investment decisions in the beginning, the process of location choice, the issues encountered in corporate management, the responses to the requirements of local institutional mandates, and how they evaluated the future of business when China gained WTO membership. The interim framework focused on the research topic, and simultaneously, exposed feedback on the original hypotheses from the empirical investigation. As more information was gathered, the points were sharpened and issues that are more critical were raised in the interviews. In the corporate interviews, in particular, I was careful to double-check each interview finding. These interviews typically lasted about one hour. In addition to the interviews, a number of shop-floor visits were made with the permission of the owners. These gave me a "genuine" picture of the cross-strait investments. Most of the interviews were recorded. Notes were also taken in the course of the interviews. I discussed the findings, encoded the information, and worked to challenge each other's viewpoints.

In the second stage, a quantitative survey on the investment activities of the top 100 IT firms in China was conducted between February and July 2004. ${ }^{6}$ It aimed to provide first-hand data on the newly emerging activities of research and development (R\&D) conducted by Taiwanese IT investors in China. The exact number of responses is 26; the response rate reached 26 percent and constituted a reliable analytic database.

\section{Relocation Strategy before the Mid-1990s: The Export Enclaves}

Encountering new institutional environments, Taiwanese investors had to reestablish their own production networks and effective governance systems. To work these out, they assessed the possibility and limitation of local sourcing and adjustment.

Understanding local institutional regulation and enforcement is critical for Taiwanese investors to operate their business. Among the institutional regulations, the tax and custom 
Table 1. The Company Profiles of IntervieWed PC Firms.

\begin{tabular}{|c|c|c|c|}
\hline & Main business & No. of employees & Location of operation \\
\hline D & $\begin{array}{l}\text { power management, video } \\
\text { display, component, } \\
\text { networking, } \\
\text { electromechanic }\end{array}$ & $>10,000$ (group) & $\begin{array}{l}\text { Dongguan }(P)^{a} \text { Kunshan } \\
(Y) \text {, Shanghai }(Y)\end{array}$ \\
\hline$D 1^{b}$ & screw nuts & About 200 & $\begin{array}{l}\text { Dongguan }(P) \text {, Wujiang } \\
\quad(Y)\end{array}$ \\
\hline D2 & Plastics & N.A. & $\begin{array}{l}\text { Dongguan }(\mathrm{P}) \text {, Kunshan } \\
\quad(\mathrm{Y})\end{array}$ \\
\hline D3 & Plastics & $<500$ & Shunde $(P)$, Wujiang $(Y)$ \\
\hline $\mathrm{F}$ & $\begin{array}{l}\text { Computer components, } \\
\text { cable, electromechanic } \\
\text { parts }\end{array}$ & $>10,000$ (group) & $\begin{array}{l}\text { Shenzhen }(P) \text {, Kunshan } \\
\quad(Y)\end{array}$ \\
\hline F1 & Electronic parts & N.A. & $\begin{array}{l}\text { Dongguan }(P) \text {, Kunshan } \\
\quad(Y)\end{array}$ \\
\hline $\mathrm{F} 2$ & electronic parts & N.A. & Shijie $(P)$, Kunshan $(Y)$ \\
\hline F3 & plastics & 350 & Kunshan (Y) \\
\hline $\mathrm{F} 4$ & molding development & 150 & Kunshan (Y) \\
\hline$A$ & $\begin{array}{l}\text { PC peripherals, monitor, } \\
\text { mobile phone }\end{array}$ & 8,000 & Suzhou (Y) \\
\hline A1 & machinery, molding & 2,000 & $\begin{array}{l}\text { Dongguan }(P), \\
\text { Shenzhen }(P), \\
\text { Shanghai }(Y)\end{array}$ \\
\hline $\mathrm{A} 2$ & molded cable, adapter & N.A. & Shanghai $(Y)$ \\
\hline A3 & precision machinery & 800 & $\begin{array}{l}\text { Shenzhen }(P) \text {, Shanghai } \\
(Y)\end{array}$ \\
\hline A4 & plastics & N.A. & Shanghai $(Y)$ \\
\hline A5 & plastics & N.A. & Wujiang (Y) \\
\hline A6 & screw nuts & about 500 & $\begin{array}{l}\text { Guangzhou }(P) \text {, Wujiang } \\
\quad(Y)\end{array}$ \\
\hline A7 & wire harness & N.A. & Wujiang (Y) \\
\hline A8 & plastics & about 800 & $\begin{array}{l}\text { Dongguan }(P) \text {, Wujiang } \\
\quad(Y)\end{array}$ \\
\hline A9 & $\begin{array}{l}\text { Silicon anode cap, focus } \\
\text { pack }\end{array}$ & N.A. & Wujiang (Y) \\
\hline A10 & plastics & about 700 & Shunde $(P)$, Wujiang $(Y)$ \\
\hline A11 & electronic parts & N.A. & Huizhou $(P)$, Wujiang $(Y)$ \\
\hline A12 & electronic parts & about 500 & Dongguan $(P)$, Wujiang \\
\hline
\end{tabular}


TABLE 1. (CONTINUED)

\begin{tabular}{|c|c|c|c|}
\hline & Main business & No. of employees & Location of operation \\
\hline A13 & cables & N.A. & Wujiang (Y) \\
\hline A14 & electronic parts & about 1,000 & $\begin{array}{l}\text { Dongguan }(P) \text {, Kunshan } \\
\quad(Y)\end{array}$ \\
\hline A15 & plastics, electronics & N.A. & Kunshan (Y) \\
\hline A16 & plastics & N.A. & Suzhou (Y) \\
\hline I & $\begin{array}{l}\text { notebook PC, sever } \\
\text { system, wireless internet } \\
\text { applicance, translator } \\
\text { machine }\end{array}$ & $>5,000$ & Shanghai, Kunshan (Y) \\
\hline 11 & electronic parts & N.A. & Kunshan (Y) \\
\hline 12 & electronic parts & N.A. & Kunshan (Y) \\
\hline 13 & wire harness & about 700 & $\begin{array}{l}\text { Dongguan }(P) \text {, Kunshan } \\
\quad(Y)\end{array}$ \\
\hline 14 & precision machinery & N.A. & Shanghai $(Y)$ \\
\hline 15 & molding & about 200 & Shanghai (Y) \\
\hline 16 & plastics & N.A. & $\begin{array}{l}\text { Shenzhen }(P) \text {, Shanghai } \\
\quad(Y)\end{array}$ \\
\hline M & scanner & $>1,000$ & Wujiang (Y) \\
\hline L & mice & $>1,000$ & Suzhou (Y) \\
\hline W & PCB products & about1,500 & Kunshan (Y) \\
\hline FC & motherboard & $>5,000$ (group) & $\begin{array}{l}\text { Guangzhou }(P) \\
\text { Kunshan }(Y)\end{array}$ \\
\hline C & notebook PC & $>3,000$ & Kunshan $(Y)$ \\
\hline$A D$ & monitor, LCD screen & $>1,000$ & $\begin{array}{l}\text { Dongguan }(P) \text {, Wujiang } \\
\quad(Y)\end{array}$ \\
\hline
\end{tabular}

a $\mathrm{P}$ connotes Pearl River Delta; $\mathrm{Y}$ indicates Yangtze River Delta. A number of firms have plants outside of both regions, such as Xian, which are not included in the table.

b For anonymity purposes, the first character "D" means subcontractor or supplier of Delta group. The rest can be reasoned by analogy.

rules raise most anxieties for the inward investors. ${ }^{7}$ According to China's state laws, foreign investors can be exempted from between 15 percent to 24 percent of income tax, but the final deals between the foreign investors and local governments will vary depending on the bargaining powers of both parties (Li and Yeung 1999). Most Taiwanese investors relocate their plants to China to gain tax and land subsidies at the initial stage. According to a survey, over 58 percent of Taiwanese investors are engaging in original equipment man- 
ufacturing (OEM) business and mainly exporting to the U.S. market (MOEA 2001). They usually import raw and intermediate inputs from overseas, mainly Taiwan, then process and assemble the products, and finally export to the final markets. As these investors enjoy preferential dealings, they are not allowed to sell products locally without special permission. Otherwise, they will be charged for smuggling, which is severely punished, carrying even the possibility of a death sentence in China. As a result, foreign investors have to manage the material inputs carefully and pay additional tax if they change to sell products locally. ${ }^{8}$

To handle the tax and custom issues, Taiwanese investors usually take careful measures to avoid getting into trouble. In the early stage, most Taiwanese investors chose to adopt joint ventures with local village and township enterprises (VTEs) and let the latter take charge of dealing with administrative matters, as they were usually part of the administrations. In spite of the local counterpart that occupied a number of positions such as vice president and manager, in most cases, they were powerless in running the joint venture. In other words, it is a kind of "fake joint venture, real foreign direct investment" (Wu 1997). These VTEs were paid in dividends or other benefits in returns, and thus drew extra costs to Taiwanese investors. Firms shield their core competence against external disturbance by blurring their boundaries to handle uncertainty in the new regions (Hudson 2001). For Taiwanese investors, the socio-economic space of China was both a land of cheap labor and potential market and the place of turbulent institutions and dull practices at that time. Therefore, it made sense for the Taiwanese investors to use local partners as the organizational buffer to fortress their supposedly superior intra-firm management and inter-firm production system from institutional disturbance in the hosting regions.

Besides the hassles from tax and custom systems, Taiwanese PC firms had to reconstruct the logistic supports and production system. Generally speaking, they had two options to choose from: either outside sourcing or inside making. For Taiwanese SMEs, conventional wisdom led them to conceive of vertical integration as not the best policy in a volatile new economy. They preferred to keep a number of key parts in their own embrace and subcontracted most of the components to trusted manufacturers. The case of Acer Peripherals exemplifies the point.

Acer Peripherals (renamed as BenQ after 2003) expanded its overseas operation to Suzhou in $1994 .^{9}$ In the beginning, they tried to find local qualified subcontractors for the production purposes but soon gave up the idea and contacted their original partners in Taiwan. As narrated by Mr. Pan, the former vice president of Acer Peripherals (Suzhou) who was in charge of the early plant construction and operation:

I was instructed to reconstruct the 'industrial infrastructure' in Suzhou as soon as possible. The infrastructure meant the collaborative manufacturing system. To get the job done, I traveled to Suzhou and the neighboring cities, even to Ningpo of Zhejiang Province which was noted for having good molders, to find if any qualified industrialists could become part of our subcontracting system, but I failed to find any with the right qualifications. Their molding technical level could not match our precision requirements. In spite of a number of local component makers who could offer lower prices than our 
original ones, the key criteria of a successful subcontractor included not only low costs but also the capability for engineering change to match our demands. I estimated that competent subcontractors would not be available within the next $3-5$ years. ${ }^{10}$

Local sourcing was often taken as the best policy for multinationals to optimize the resource allocation and save costs (Dunning 1993). In fact, Taiwanese investors like Acer Peripherals tried to source locally at first, but they could only resort to other options as the local environment could not make available the necessary skills and quality.

The alternative was to move the whole subcontracting system altogether. This strategy was dubbed "the hen brought little chickens together." ${ }^{11}$ Acer Peripherals did ask more than twenty subcontracting partners to visit potential sites in 1993 and finally fourteen decided to follow. These subcontracting firms consisted of specialists in precision machinery, plastic ejection, cable assembly, and even varieties of screws. All of them clustered in the Wujiang Economic Development Zone, within one-hour driving distance from Suzhou. Most of the subcontractors had more than five years working relationship with the core firm, Acer Peripherals. The long-term stable relationship helped Acer Peripherals convince the collaborators to move together though there were not any written documents to guarantee the success. As Mr. Hsu of KuaoLeng Electronics Co., a screw maker partner of Acer Peripherals, pointed out:

Acer Peripherals approached us and asked if we would like to follow them to China in 1993. More than 80 percent of our capacity was ordered by them, and if they moved, and we did not move together, I was not sure if we could find replacement orders.... They did not have to give us any written promise and we knew each other well. They trusted our capabilities and we were not easily replaced. ${ }^{12}$

The previous social relations persuaded the subcontracting firms to take the move and helped the core firms to reproduce their supply chains quickly in the alien land. In a sense, the social embeddedness of Taiwan was transferred across the strait and worked well in sustaining production networks without outside disturbance in China.

More component subcontractors were gradually drawn to the core firm's geographical orbits as the latter mandated, otherwise, the former would lose business. As a result, almost the whole Taiwanese "chickens nest" moved to the YRD. The main exception to this process were certain $R \& D$ jobs relating to the molding process and products with high precision requirements which local technical skills could not match. These remained in Taiwan. The trend of attracting subcontractors across the strait led to the share of material and intermediate input procurements of Taiwanese investors from the donor country to decline from 27.04 percent in 1993 to 18.2 percent in 1998 (Kao 2000).

Problems of transferring the production system also appeared in the context of labor regulation. Most Taiwanese PC investors, particularly those in the PRD, hired people, mostly young women in their twenties or younger, from rural areas (ming-gong), by paying them in the range of RMB $\$ 400$ to 700 dollars per month (Zhu 2001). Even those located in YRD, with its previous industrial base of state-owned enterprises (SOEs), purposely avoid recruiting experienced workers and rather choose to employ labor from other rural regions, such as Anhui Province, Hunan Province, and even the North of Jiangsu Province 
(Subei). By doing so, Taiwanese investors could "produce" the labor force at will, and circumvent the limitations of existing industrial practices in the collectivist SOEs. A number of interviewed managers listed the "bad habits" of the veteran workers, including irresponsibility, opportunism, and gaining extra advantage at the public expense. "We would like to hire a novice, rather than an old hand with 'bad habits'. As far as an old hand was concerned, first you had to let him/her forget the traits that he/she had lived with for a long time. It was much more difficult than teaching an employee from nothing." 13 To control and train labor effectively, each Taiwanese PC investor dispatched numerous cadres (Tai-Gan) from mother companies to the subsidiaries in China. ${ }^{14}$ These expatriates generally played the roles of both overseers and taskmasters in the factories. They were the pillars of the Taiwanese firms and alleviated the frictions accrued in the acclimatization process. They transferred their technical skills and industrial practices to the new plants.

Besides labor control on the shop floor, most Taiwanese investors constructed bulky dormitories to house their workers from other towns and imposed strict rules such as curfews to discipline their off-duty lives. The labor control occurred not only in the workplace but also extended to the reproduction areas (Castree et al. 2004; Jonas 1996; Storper and Walker 1989).

By and large, Taiwanese investors chose to respond strategically to the tensions caused by the process of transition to the alien institutional environments of China in the late 1980s to mid-1990s. They adopted fake joint ventures to circumvent the cumbersome tax and custom issues, implanted entire subcontracting chains, and sent out cadres to manage labor training and regulation issues. Because most Taiwanese PC investors came to China to take advantage of cheap labor for export, the best ways to govern cross-strait investments was to keep their competitive production systems as intact as possible. In other words, they adopted relocation strategies to prevent local interruption and in so doing, they could enjoy the benefit of substantial tax subsidies and low labor costs and remained spontaneously competitive in the production systems. This demonstrates that firms may serve as a transmission vehicle for best practices for the hosting regions and thus their organizational configurations and business strategies may remain as intact as possible so that they can insulate themselves from local disturbances (Hardy 1998; Kenney and Florida 1993). They can relocate their whole industrial system to the new territory.

\section{Localization Strategy after the Mid-1990s: The Emergent Local Market}

In contrast, firms might choose to harness local links with their surrounding institutions and mobilize new resources to augment their assets (Dunning 1998; Rutherford 2000). They could embed locally in new territories. The process of internationalization is full of learning by trial and error during the construction of supply chain, the development of labor regime, and the engagement of market probing.

The situation changed as China's market emerged and gradually opened further to foreign investors after the mid-1990s. Exploring the huge internal Chinese market became the mandate for Taiwanese investors to prosper. Accordingly, their management and oper- 
ation systems evolved around different principles from previous "enclave" strategies. At the same time, China's institutional environments had been under reform since the National State Council acted on a series of corruption scandals in the coastal cities and promised to tackle the issue of barriers to trade under the new Premier Zhu in 1998. Tax and custom administrations were reshuffled and there was some evidence of a gradual shift from personal particularism to impersonal universalism in the most developed area, such as the YRD, in China (Guthrie 1998). ${ }^{15}$ Local governments in the YRD have learned from previous bargaining experiences with foreign investors to recognize that improving their efficiency in administrative procedures and the spirit of "rule of law" is more critical than hardware infrastructure construction in attracting foreign investments (Chang and Chiu 2000). Besides, to encourage more Taiwanese high-technology investments, local governments established closer relations with investors and demonstrated their prodevelopment policies. As these investors learned from interactions with local institutions, they gradually moved to a closer network relation (Chen 2003). At the same time, the hosting regions learned from the interactions too and adjusted their institutional arrangements to match firms' demands, and thus a firm-territory nexus evolves (Dicken and Malmberg 2001).

Closer interaction could be validated by the roles played by the Taiwanese investors associations (TIAs), which were set up in various key host cities, such as Shanghai, Dongguan, Suzhou, and Kunshan. More than fifty such associations spread over the coastal regions. In addition to the traditional role of policy lobbyists and problem reflectors, they gradually became involved in agenda setting for the regions. The case of the Kunshan association is particularly relevant here. As a major site of a cluster of Taiwanese IT firms, Kunshan was aggressively promoted by its city government as the image of "Little Taipei." To enhance the attraction, Kunshan city government collaborated with the Kunshan TIA to organize a taskforce to invite a number of senior urban planners from Taiwan to contribute to drafting a comprehensive strategic plan in 2002. The plan was to provide guidelines for industrial and city development in the next decade. Moreover, they together initiated an annual Kunshan-Taiwan forum, and invited scholars and experts from the Taiwan side to discuss the developmental experiences that Kunshan could learn from Taiwan in many aspects covering fiscal management, city planning, industrial policy, and governance digitalization. The forum was held for three consecutive years from 2001-2003 and acted as a platform for the city government and Taiwanese investors to discuss and monitor key issues with the help of Taiwanese experts. In a sense, local governments, as reflexive agents, learned to construct regional advantages to attract Taiwanese investments. Morgan (2004) argues that regions, based on a broad set of regional actors such as politicians, policy makers, industrial associations, and research institutes, can interact in innovative ways to define new competitive strategies in the global economy.

In the new situation, Taiwanese investors started to build up local links, such as markets and technologies and increased their share of local procurement. ${ }^{16}$ First, they had to solve the tax and custom matters as they shifted from export orientation to local targeting. In accord with the rules, foreign investors should pay back the tax subsidies and make a clear distinction between the materials for exports and those for the local market, otherwise, 
they could be considered as smuggling. Consequently, some Taiwanese investors would rather set up new independent companies to be responsible of local marketing ${ }^{17}$ or at least split up the local marketing division from other departments in the firm's organization.

To build good relations with local key customers, investors had to make transformations in organization. The transformations appeared in two aspects. On the one hand, by subcontracting, the major electronics groups in China, such as Legend Computers, might help the Taiwanese SMEs to penetrate the local market, which appeared open but in reality were behind major barriers. On the other hand, the collaboration could also extend to new product development, which might match the local demand. The collaborative project between Taiwan's First International Computer (FIC) Group and China's Legend Computer Group is an example of this relationship. To facilitate the collaborative project, FIC sent out a team of several key engineers to Legend's new plant in Shanghai to develop new products such as notebook computers. In return, FIC established a stable subcontracting relation with the largest local computer group in China. ${ }^{18}$

Another famous instance was the joint ventures made by Foxconn Group with promising startups founded by local engineers to access the emerging product areas of wireless telecommunication. These investments were to target new product development and to enhance the innovative activities for the Foxconn Group in China. ${ }^{19}$ They were different from the fake joint ventures as observed in the previous stage. As revealed by the quantitative survey shown in Figure 3, most of the top 100 IT Taiwanese investors took the factors such as "near customer" and "developing closer partnership with local companies" as the most critical factors in attracting their investments in China.

The local market imperative is not just confined to Taiwanese investors' usual practices as subcontracting partners for key PC buyers, but also extends to the possibility of meta-

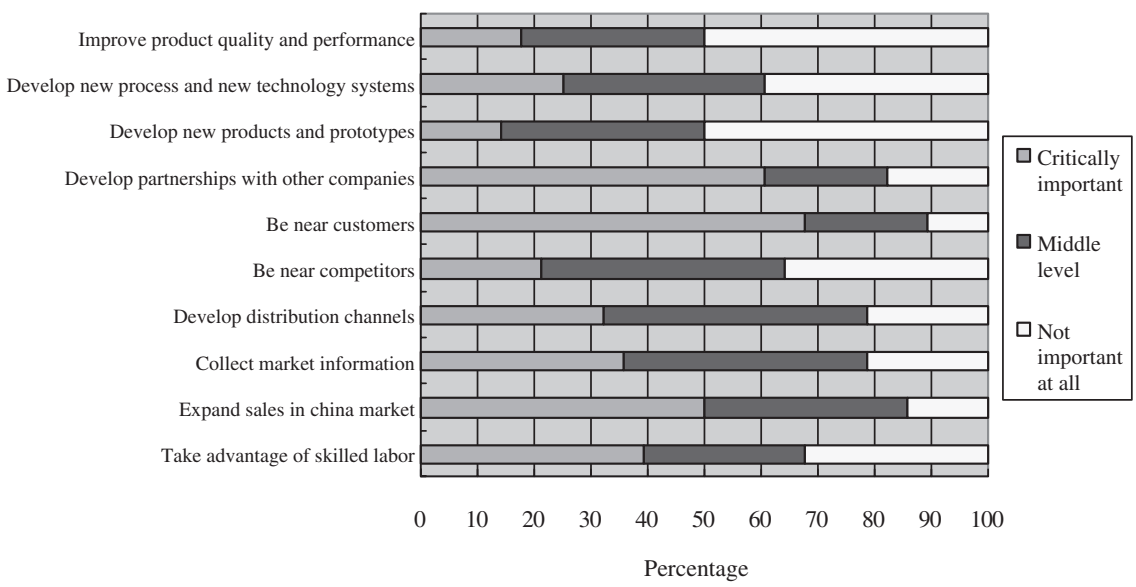

Figure 3. THE IMPORTANCE OF REASONS FOR LOCATING FIRMS AND OPERATIONS IN CHINA $(n=26)$. 
morphosing as their own brand-name $(\mathrm{OBN})$ makers. Becoming an $\mathrm{OBN}$ producer was a totally new and complex development for most Taiwanese PC investors, who were long known for their hidden OEM factories in global production networks (Lin 2000). It required not only production capabilities, which most Taiwanese PC investors knew quite well, but also marketing competence, which consisted of the tacit knowledge about local tastes, specific standards, and exact regulations, to make a way into the long-fortressed China market.

To meet the challenge of being OBN makers, Taiwanese IT firms had to cautiously steer their investments toward $R \& D$ to add value and at the same time, toward production improvement to reduce the cost of manufacturing if they were to remain competitive (cf. Hobday 2003). Before fully embracing the OBN strategies, most of the PC makers adopted an experimentalist policy to handle the new situation. Often they kept OEM orders with their buyers while launching a small range of new products on to the China market, which they had cultivated for over a decade. For example, Mr. Lee, the CEO of BenQ, recalled his OBN experience as similar to the transition of Socialist China in "crossing the river by touching the stones":

Before initiating our own cellular phone, we set up a team composed of local marketing people, industrial designers and skilled engineers to explore the probability of success. We are still maintaining the business partnership with our key buyers such as Motorola. Once we find the timing is mature, China's government is more than likely to sanction licenses for new makers to distribute cellar phone products in China so we decided to give our OBN products a try. (Zhuang, Chen, and Chen 2001)

Figure 4 demonstrates that the major subsidiaries for IT Taiwanese investors reside in the areas of local operation such as the distribution and marketing capabilities and these constitute the basis of local knowledge that is beneficial for own-brand buildup.

In fact, the research survey of the operation of the top 100 IT Taiwanese firms in China shows that over 85 percent have started to set up R\&D arms in China in the past five years (1999-2004). It also indicates that 40 percent of the firms reported "the availability of skilled labor" as being critically important and another 30 percent as somewhat important. Indeed, there has been a rising trend to the $R \& D$ activities of transnational corporations within developing countries despite the conventional view that R\&D operations are, basically, phenomena of developed countries (Reddy 2000). This is particularly relevant for East Asian latecomers, which are expanding their business operation outwards and concentrating on the second-tier industrializing countries such as China and the Southeast Asian countries (Chen 2004; Hoesel 1999; Lu and Liu 2004; Sim and Pandian 2002). ${ }^{20}$

As a result, a number of Taiwanese IT investors started to develop their brand-name products in China, and their Chinese subsidiaries have become more autonomous than in the earlier stage. Inventec Group is a good example here. It was noted for its early establishment of local innovation teams to develop products such as translator appliances and for selling the products locally. As Mr. Huang, vice president of Inventec (Shanghai) stated:

We had been OEM partners for key international electronics buyers for a long time. We could never dream of creating our own brand products until we arrived at Shanghai. However, selling products in 


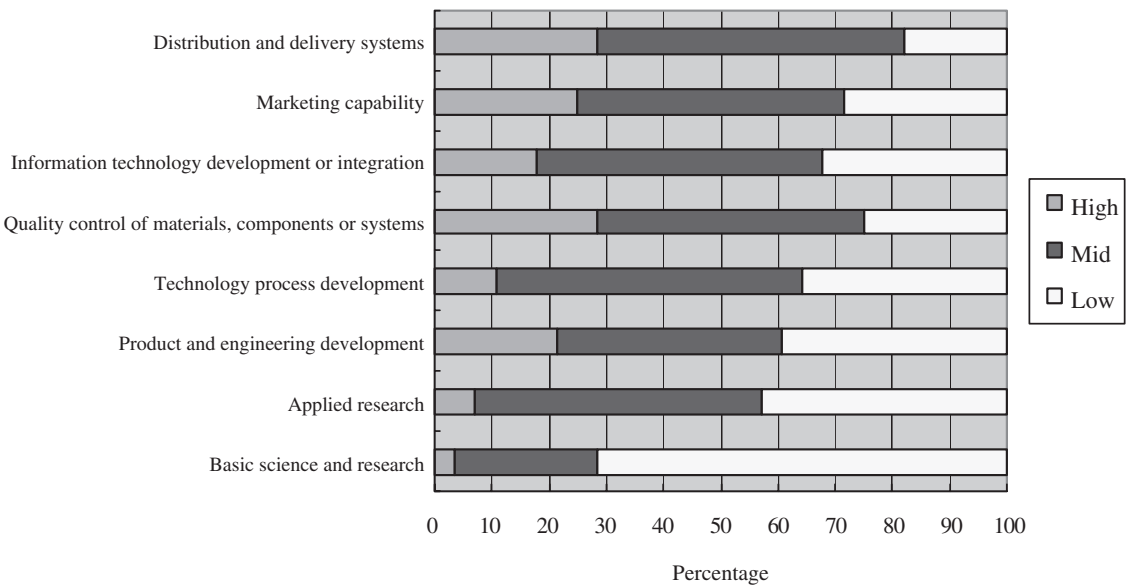

Figure 4. The CoRRELATION OF TAIWANESE INFORMATION TECHNOlogy FiRms' Technology or ORganizational DeVelopment In China With TheiR HEADQUARTERS IN TAIWAN $(n=26)$.

China was not a piece of a cake, even though we, Chinese, shared the same culture. So, we hired local qualified people with product design capabilities and marketing experience to lead the division. They usually needed guidance in the beginning but they could adjust themselves very quickly. ${ }^{21}$

The localization efforts led a number of Taiwanese investors to start their own brand of products, so that, for example, Acer Peripherals switched from being a member of Acer group to the independent BenQ brand maker, Quanta Computer sold its products under the name of Getac in China, and the Inventec Group promoted its Okwap cellar phones in the Chinese domestic market in 2001. The quantitative survey also confirmed this trend, as shown in Figure 5 In some sectors, such as telecommunication, software, and even electronic components, the positions of the subsidiaries increasingly gained weight, even sometimes becoming totally autonomous from their headquarters in Taiwan.

The emergence of localization strategies was quite a new phenomenon. Even in a survey conducted in 2002, about 75 percent of IT firms take support from the parent as their key technology sources for their subsidiaries in China. At the same time, nearly 80 percent of the surveyed firms agreed that local subsidiaries' own R\&D efforts have become the first or second major source (Chen 2004). A huge pool of local talent has been identified as the key advantage to attract Taiwanese investors to engage in R\&D activities locally. To recruit qualified engineers, a number of IT firms such as BenQ and Invetec have set up scholarship programs with the local universities such as Suzhou University and Jiaotong University (Shanghai) to get first contact with the most capable students. In accordance with the trend, some of the local governments and technology park administrations 


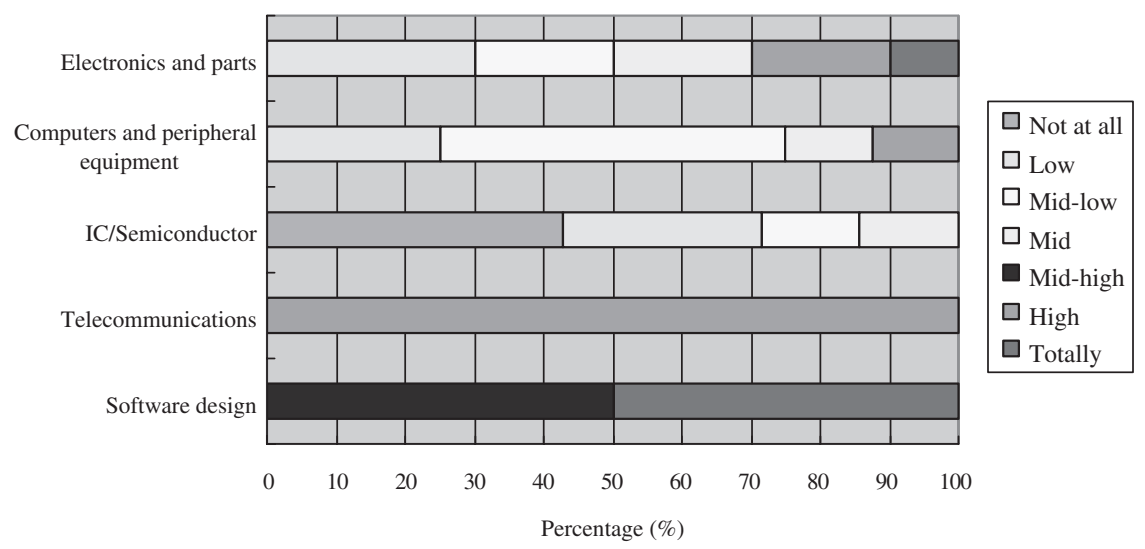

Figure 5. Autonomy of Firms in China fRom HeAdquarters (By Sector) $(n=26)$.

in the PRD region have even planned to set up new universities to fulfill the engineer demand locally.

The issue of how to train and regulate talented people has become critical for Taiwanese investors in this new stage of competition. In contrast to the early stage when cheap labor was the main concern, the engagement in $\mathrm{R} \& \mathrm{D}$ activities has required a more humane and reasonable labor control. As Mr. Huang of Invetec added, "you can not press the brains to innovate, but you can provide incentives to encourage them. We hired people and trained them. Moreover, we offered high wages to attract them and mock our working environment in Taipei to make them comfortable. Otherwise, the engineers would hop to another company. It's Shanghai, not Dongguan, here. Lots of high-wage jobs floated over here. You had to fight with other competitive companies to ensure that people stayed." More formal working rules pertaining to promotion, wage increases, bonus job security, and job rotation were introduced, and more opportunities for participating in technical courses were offered. In a sense, human resource management activities should be an integral part of the risk management of international investment decisions at the networking stage, regardless of the cultural distance between home and host cultures (cf. Fenwick, Edwards, and Buckley 2003).

The addition of R\&D operation in China has caused issues of coordination and governance for Taiwanese investors. As numerous key R\&D tasks were still kept in Taiwan, the role and function of those $\mathrm{R} \& \mathrm{D}$ activities in China had to be specified to avoid conflict and enhance efficiency across the strait. Hsien of FIC (Shanghai) explained:

We had to set up a division of labor between our Taiwan R\&D team and that in Shanghai, otherwise, they might do the same things without creating synergy. We could not let the Taiwan team think they would be replaced by their counterparts in Shanghai, and could not let the Shanghai team think they 
were just playing a marginal role either. We created mechanisms to allow both to compete in some products and to cooperate in others. We also send engineers to visit each other to help them to understand what the culture was like on the other side. By doing so, they could share with each other and get jobs done.

It was obvious that governing cross-border $\mathrm{R} \& \mathrm{D}$ activities would become difficult as localization strategy involved more conflicts between different teams from divergent work practices and relevant institutionalized behaviors, or divergent time-space strategies (Schoenberger 1997).

Incorporating new divisions to mobilize new resources and engaging in new activities in the host regions resulted in the reshuffling of the organizational fields (Poon, Hsu, and Suh 2006). It involved the process of organizational decoupling and recoupling and engendered governance tensions within the organization and outside institutional arrangements. It is still too early to identify all the details of the trend of organization-institution interaction between Taiwanese investors and China's emerging market. In fact, other possible trajectories taken by Taiwanese investors still exist if the promise of opening China's market is not fully realized in the future. It might force Taiwanese firms to withdraw from the OBN attempt and return to the OEM model. Nevertheless, a new pattern of firmterritory nexus has occurred in the regionalization of investment. A summary table that distills and contrasts the key characteristics of the two FDI regimes (pre- and post-1997) is illustrated in Table 2.

\section{Conclusion: Reflections on Institutionalism and Territory-Firm Nexus}

This research resonates with the arguments of Gertler (2001) that "any revised theory of firm practice must take adequate room for individual, collective and corporate agency within the firm" (20). It contends that firms should be regarded as economic units with power (Maskell 2001; Prahalad and Hamel 1990; Teece and Pisano 1994), which can mobilize their resources to colonize their threatened environment without transforming themselves in the least. In this regard, the firm theory most appropriate for economic geography should be to take the firm seriously, identify its internal competence, and clear its boundaries in the process of institutional (re)embeddedness, rather than just viewing it as social networks with blurred limits as advocated by Dicken and Malmberg (2001). By doing so, it is possible to bring the firm back in as an agent with a different proactive capacity or power structure, and then to further decode the peculiarity of the firm-place nexus in different times and geographies (Hudson 2001; Yeung 2005, 2002).

From the perspective of regional development, this study has demonstrated the limitations of a number of endogenous theories that prioritized social capital and institutional thickness over power relationships and political economy (Fine 2001; Lovering 1999). This research demonstrates that different modes of institutional embeddedness may create various effects in divergent times and geographical scales: Taiwanese IT SMEs took advantage of guanxi or flexible citizenship (Ong 1999) as relational assets in the beginning of 
TABle 2. A Summary of the Difference Strategies Adopted by Taiwanese INVESTORS.

\begin{tabular}{|c|c|c|}
\hline & $\begin{array}{l}\text { Relocation strategy } \\
\text { before mid-1990s }\end{array}$ & $\begin{array}{l}\text { Localization strategy post } \\
\text { mid-1990s }\end{array}$ \\
\hline Type of investment & $\begin{array}{l}\text { Fake joint venture with } \\
\text { VTEs }\end{array}$ & Foreign direct investment \\
\hline Supplier relationship & $\begin{array}{l}\text { Source key inputs from } \\
\text { Taiwan }\end{array}$ & $\begin{array}{l}\text { Move the key suppliers to } \\
\text { China }\end{array}$ \\
\hline Labor source & Cheap labor & Skilled labor \\
\hline Labor control & $\begin{array}{l}\text { Strict shop-floor control } \\
\text { by Taiwanese cadres }\end{array}$ & Promote local managers \\
\hline $\begin{array}{l}\text { Business-Government } \\
\text { relation }\end{array}$ & $\begin{array}{l}\text { Guanxi game to avoid } \\
\text { disturbance }\end{array}$ & $\begin{array}{l}\text { Mutual learning to improve } \\
\text { investment environment }\end{array}$ \\
\hline $\begin{array}{l}\text { Organizational } \\
\text { configuration }\end{array}$ & Mostly assembly line & $\begin{array}{l}\text { Add R\&D and Marketing } \\
\text { team }\end{array}$ \\
\hline $\begin{array}{l}\text { Position in production } \\
\text { chains }\end{array}$ & OEM expansion & ODM and OBN transition \\
\hline
\end{tabular}

VTE, village and township enterprises; R\&D, research and development; OEM, original equipment manufacturing; Original Design Manufacturing; OBN, own brand-name.

cross-border investment at the international level and buffered themselves from disorders in state regulations in the PRD, and they moved to comply with the formal regulations and made use of the YRD regional advantage at the domestic level as China's internal market emerged. The key issues for the regions here were not to establish much thicker institutions but to learn to monitor the firm-region interaction by experimenting with institutional adjustment (Henderson 2000; Sabel 1996). This point needs highlighting because the recent "institutional turn" in economic geography is wont to give the impression that institutional thickness mattered as much as, if not more than, the firms at the heart of regional development (Hudson 1999; Morgan 2004).

Echoing Yeung (2005) in a recent issue of this journal, this research has demonstrated how the firm serves as a relational institution that connects spatially differentiated actors in different places and regions and shows that cross-border IT investors have adopted divergent strategies to disconnect and reconnect with hosting regions with the goal of strengthening the firm's core competence. As a result, firms' investments changed the developmental trajectories of the host regions (firming place), and at the same time, the regions imbued the firm with their regional stamp (placing firm). Relocation and localization, in this analytic vein, could be geographically sensitive strategies for firms, as reflexive agents, to protect and to reinforce their competence in the evolution of the firm-territory nexus. 


\section{NOTES}

1. According to Chung (1997), the estimated cost savings (including material cost, direct labor, and indirect labor) to Taiwanese PC companies ranged from 22 percent in mice production, to 8 percent in monitor making in comparison with offshore manufacturing in China in 1993. The range was between 16 percent and 4 percent compared with Malaysia.

2. In a questionnaire conducted by Taiwan's Ministry of Economic Affairs, 81.9 percent of the Informatics firms' interviewees agreed that the huge potential market in China was the key to pull Taiwanese investors. In addition, 73.5 percent of the correspondents thought the IPOs' requests of the key buyers was one of the major forces to push them to move operations across the strait (MOEA 1999).

3. As Hess (2004) illustrated, different dimensions of embeddedness refer to different relations between the social agents (firms and nonfirm) and other sociospatial actors. Among them, network embeddedness and territorial embeddedness were particularly relevant in this article. While the former refers to a process of trust building between network agents, the latter means that economic actors absorb, and in some cases become constrained by, the economic activities and social dynamics that already exist in those places.

4. Because of the "don't rush, be patient" policy stipulated by the former president Lee Teng-hui, lots of Taiwanese investors, particularly those high-technology firms, would choose to register in third countries, such as the Caiman Islands, as foreign companies to engage in Chinese investments, rather than report to the government. Thus, it is often alleged that official cross-strait investment records are less accurate than those kept by the investment consulting companies.

5. Among these fifty firms, twenty-six belong to the category of PC industry, and fifteen of them have engaged in FDI in China.

6. The targeted populations were based on manufacturing firm directories obtained from the top 100 high-technology IT firms in the database of various business journals such as Common Wealth and Business Next.

7. According to a survey, custom and tax administrations in China are identified respectively as either the most ( 76.3 percent) or the second-most ( 60.8 percent) bothersome issue by Taiwanese investors. They are rated as much higher than the third highest complaint, the labor bureau, which received 15.2 percent of the responses (MOEA 2001). Typically, investors applied to the customs based on the contracted prices but were paid market prices, which were typically higher than the contracted ones, in business transactions. This led to disparities between the custom tax accounts and company financial ones and frequently incurred criminal charges of tax evasion.

8. In accord with the laws on special economic zones, all final products have to be exported to qualify for business tax breaks, and they are only allowed to sell locally under condition of special permission by the governments and must pay the 17 percent business tax.

9. Before the Chinese subsidiary, Acer Peripherals had set up another plant in Malaysia in 1989. The product groups included CRT monitors, LCD monitors, LCD projectors, DVD players, telecommunication systems, and cellar phone products.

10. J.-S. Pan (deputy managing director, Darfon Electronics Co., Suzhou), interview by J.-Y. Hsu, May 23, 2001.

11. In fact, this strategy was adopted by other core PC makers, such as Inventec Group, a top notebook computer maker in Taiwan, who brought more than forty subcontractors to visit sites before settling in Shanghai in 1997. The subcontracting firms regularly meet to discuss issues of law 
interpretation, tax matters, labor control, and other management problems. They dubbed the meeting as the "Inventec association."

12. J. Hsu (general manager, KuaoLeng Electronics Co.), interview by J.-Y. Hsu, June 25, 2001.

13. M. Lee (vice president, WUS Printed Circuit Group), interview by J.-Y. Hsu, December 5, 2001.

14. The number of expatriates varied in different scales and sectors of firms. Basically, the larger the firms, the more they needed overseers. In addition, the more sophisticated the sector, the more taskmasters were required. According to the report, 72.1 percent of Taiwanese inward companies had less than five Taiwanese managers, 19.1 percent less than ten, and only 0.3 percent over twenty cadres from Taiwan (MOEA 2001).

15. Yang (2002) cast doubts on the argument about the decline of guanxi in China and insisted that the practice of guanxi might be replaced by the legal system in some economic areas, but it would arise in others. Nevertheless, she agreed that the dynamic evolution of the institutional environment, particularly the establishment of a stable legal system, would increasingly gain influence in the business practices in China.

16. According to a recent survey by the Ministry of Economic Affairs, the share of local procurement by Taiwanese investors in Mainland China has reached 61.4 percent of the total intermediary inputs, in comparison with 14.6 percent of that in Southeast Asia in 2002 (China Times, January 24, 2004).

17. For example, the Sky Hawk Computer Group established a new company to take charge of its business with local key customers, such as the Legend Computer and Haier Group.

18. B. Hsien (vice president, Electronic Design Department, FIC), interview by J.-Y. Hsu, October 21, 2001.

19. D. Qi (vice president, Foxconn, Shanghai), interview by J.-Y. Hsu, October 23, 2001.

20. As shown by Lu (2000), the growth of China's IT firms, such as Legend, comes not only from technologies borrowed from abroad, but also from genuine indigenous innovations in products and processes. The indigenous innovative capabilities were built upon the basis of substantial investment from the state partly for defense purposes in the cold war.

21. P. Huang (vice president, Inventec Group, Shanghai), interview by J.-Y. Hsu, August 16, 2001.

\section{REFERENCES}

Amin, A. 2002. Spatialities of globalization. Environment and Planning A 34: 385-399.

Benz, A., and D. Fürst. 2002. Policy learning in regional networks. European Urban and Regional Studies 9(1): 21-35.

Berger, S., and R. Lester. 2005. Global Taiwan: Building competitive strengths in a new international economy. Armonk, NY: M. E. Sharpe.

Boyer, R. 1998. Hybridization and models of production: Geography, history, and theory. In Between imitation and innovation: The transfer and hybridization of productive models in the international automobile industry, ed. R. Boyer, E. Charron, U. Jurgens, and S. Tilliday, 23-56. Oxford: Oxford University Press.

Business Next. 2000. Special issue: Top 100 Taiwanese high technology enterprises. Taipei. Business Next Journal 2(5): 3-102 (in Chinese).

Capital Group. 2001. March on China: The special issue on Taiwanese investments in China. Taipei: Capital Group (in Chinese). 
Castree, N., N. Coe, K. Ward, and M. Samers. 2004. Spaces of work: Global capitalism and geographies of labor. London: Sage.

Chang, J-M., and S-L. Chiu. 2000. Globalization and Suzhou's outward orientation economic development: A comparative study of four technology development parks. Paper presented at the Symposium of Globalization, Sunan Economic Development and Taiwanese Investment, October 31, 2000, Taipei, Taiwan (in Chinese).

Chen, S.-H. 2004. Taiwanese IT firms' offshore R\&D in China and the connection with the global innovation network. Research Policy 33: 337-349.

Chen, T.-J. 2003. Network resources for internationalization: The case of Taiwan's electronics firms. Journal of Management Studies 40(5): 1107-1130.

Cheng, L.-L. 1999. The invisible elbow: Semiperiphery and the restructuring of international footwear market. Taiwan: A Radical Quarterly in Social Studies 35: 1-46 (in Chinese).

Chung, C. 1997. Division of labor across the Taiwan Strait: Macro overview and analysis of the electronics industry. In The China circle, ed. B. Naughton, 164-209. Washington, DC: Brookings Institution Press.

Depner, H., and H. Bathelt. 2005. Exporting the German model: The establishment of a new automobile industry cluster in Shanghai. Economic Geography 81(1): 53-81.

Dicken, P. 2000. Places and flows: Situating international investment. In The Oxford handbook of economic geography, ed. G. Clark, M. Feldman, and M. Gertler, 275-291. Oxford: Oxford University Press.

Dicken, P., and A. Malmberg. 2001. Firms in territories: A relational perspective. Economic Geography 77(4): 345-363.

Dunning, J. 1993. Multinational enterprises and the global economy. Wokingham: Addison-Wesley. 1998. Location and multinational enterprise: A neglected factor? Journal of International Business Studies 29(1): 45-66.

Eriksson, J., A. Majkgard, and D. Sharma. 1997. Experiential knowledge and cost in the internationalization process. Journal of International Business Studies 28(2): 337-360.

Fenwick, M., R. Edwards, and P. Buckley. 2003. Is cultural similarity misleading? The experience of Australian manufacturers in Britain. International Business Review 12: 297-309.

Fine, B. 2001. Social capital versus social theory: Political economy and social science at the turn of the millennium. London: Routledge.

Gertler, M. 2001. Best practice? Geography, learning and institutional limits to strong convergence. Journal of Economic Geography 1(1): 5-26.

Governa, F., and C. Salone. 2004. Territories in action, territories for action: The territorial dimension of Italian local development policies. International Journal of Urban and Regional Research 28(4): 796-818.

Guthrie, D. 1998. The declining significance of guanxi in China's economic transition. The China Quarterly 154: 254-282.

Hardy, J. 1998. Cathedrals in the desert? Transnationals, corporate strategy and locality in Wroclaw. Regional Studies 32(7): 639-652.

Henderson, D. 2000. EU regional innovation strategies: Regional experimentalism in practice? European Urban and Regional Studies 7(4): 347-358.

Hess, M. 2004. "Spatial" relationships? Towards a reconceptualization of embeddedness. Progress in Human Geography 28(2): 165-186. 


\section{GROWTH AND CHANGE, JUNE 2006}

Hobday, M. 2003. Innovation in Asian industrialization: A Gerschenkronian perspective. Oxford Development Studies 31(3): 293-314.

Hoesel, R. 1999. New multinational enterprises from Korea and Taiwan. London: Routledge.

Hollingsworth, R. 1998. New perspectives on the spatial dimensions of economic coordination: Tensions between globalization and social systems of production. Review of International Political Economy 5(3): 482-507.

Hsing, Y.-T. 1998. Making capitalism in China: The Taiwan connection. New York: Oxford University Press.

Hudson, R. 1999. The learning economy, the learning firm and the learning region: A sympathetic critique of the limits to learning. European Urban and Regional Studies 6(1): 59-72.

- 2001. Producing places. New York: The Guilford Press.

Jessop, B. 2000. The crisis of the national spatio-temporal fix and the tendential ecological dominance of globalizing capitalism. International Journal of Urban and Regional Research 24: 323-360.

Jonas, A. 1996. Local labour control regimes: Uneven development and the social regulation of production. Regional Studies 30(4): 323-338.

Kao, C. 2000. The localization of Taiwanese investment in China and its effects on Taiwan's economy. Working Paper, Taipei: Cier.

Kenney, M., and R. Florida. 1993. Beyond mass production: The Japanese system and its transfer to the U.S. Oxford: Oxford University Press.

Li, X., and Y-M. Yeung. 1999. Bargaining with transnational corporations: The case of Shanghai. International Journal of Urban and Regional Research 23(3): 513-533.

Lin, G. 1997. Red capitalism in South China: Growth and development of the Pearl River Delta. Vancouver, Canada: UBC Press.

Lin, T.-L. 2000. The social and economic origins of technological capacity: A case study of Taiwan's personal computer industry. PhD diss., Sociology, Temple University.

Lovering, J. 1999. Theory led by policy: The inadequacies of the "new regionalism" (illustrated from the case of Wales). International Journal of Urban and Regional Research 23: 379-395.

Lu, Q. 2000. China's leap into the information age: Innovation and organization in the computer industry. New York: Oxford University Press.

Lu, L., and J. Liu. 2004. R\&D in China: A empirical study of Taiwanese IT companies. R\&D Management 34(4): 453-466.

Maskell, P. 2001. The firm in economic geography. Economic Geography 77(4): 329-344.

Ministry of Economic Affairs (MOEA). 1999. Survey on Taiwanese manufacturing firms' outward investments. Taipei, Taiwan: MOEA (in Chinese).

- 2001. The effect of the changing China's investment environment on Taiwanese investors' decision. Taipei, Taiwan: MOEA (in Chinese).

Ministry of Foreign Trade and Economic Cooperation. 1999. Almanac of China's foreign economic relations and trade. Beijing: China Economic Publishing House.

Morgan, K. 2004. The exaggerated death of geography: Learning, proximity and territorial innovation systems. Journal of Economic Geography 4(1): 3-21.

Ong, A. 1999. Flexible citizenship: The cultural logics of transnationality. Durham, UK: Duke University Press.

Poon, J., J.-Y. Hsu, and J. Suh. 2006. The geography of learning and knowledge acquisition among Asian latecomers. Journal of Economic Geography (in press). 
Prahalad, C., and G. Hamel. 1990. The core competence of the corporation. Harvard Business Review 68: 79-91.

Reddy, P. 2000. Globalization of corporate R\&D: Implications for innovation systems in host countries. London: Routledge.

Rutherford, T. 2000. Re-embedding, Japanese investment and the restructuring buyer-supplier relations in the Canadian automotive components industry during the 1990s. Regional Studies 34(8): 739-751.

Sabel, C. 1996. Experimental regionalism and the dilemmas of regional economic policy. Paper presented to the Conference on Socio-Economic Systems of Japan, the US, the UK, Germany, and France, Institute of Fiscal and Monetary Policy, Tokyo, Japan.

1995. Intelligible differences: On deliberate strategy and the exploration of possibility in economic life. Paper presented to the 36th annual meeting of the Society of Italian Economists, October 20-21. 1995, Florence, Italy.

Saxenian, A. 1994. Regional advantage: Culture and competition in Silicon Valley and Route 128. Cambridge, MA: Harvard University Press.

Schoenberger, E. 1997. The cultural crisis of the firm. Oxford: Blackwell.

- 1999. The firm in the region and the region in the firm. In The new industrial geography: Regions regulation and institutions, ed. T. Barnes and M. Gertlered, 205-224. London: Routledge.

Sheppard, E. 2000. Competition in spaces and between places. In A companion to economic geography, ed. E. Sheppard and T. Barnes, 169-186. Oxford: Blackwell.

Sim, A., and J. Pandian. 2002. Internationalization strategies of emerging Asian MNEs: Case evidence on Taiwanese firms. Journal of Asian Business 18(1): 67-80.

Smart, A. 1998. Economic transformation in China: Property regimes and social relations. In Theorising transition, ed. J. Pickles and A. Smith, 428-449. London: Routledge.

Storper, M. 1997. The regional world: Territorial development in a global economy. New York: The Guilford Press.

Storper, M., and R. Walker. 1989. The capitalist imperative: Territory, technology and industrial growth. Oxford: Blackwell.

Swyngedouw, E. 1997. Neither global not local: "Glcalization" and the politics of scale. In Spaces of globalization: Reasserting the power of the local, ed. K. Cox. New York: The Guilford Press.

Taylor, M., and B. Asheim. 2001. The concept of the firm in economic geography. Economic Geography 77(4): 315-328.

Teece, D., and G. Pisano. 1994. The dynamic capabilities of firms: An introduction. Industrial and Corporate Change 3(3): 537-556.

Walcott, S. 2003. Chinese science and industrial technology parks. Aldershot, UK: Ashgate.

Wang, H. 2000. Informal institutions and foreign investment in China. Pacific Review 13(4): 525-556.

Wu, J.-M. 1997. Strange bed-fellows: Dynamics of government-business relations between Chinese local authorities and Taiwanese investors. Journal of Contemporary China 6: 315-346.

Yang, M. 2002. The resilience of guanxi and its new developments: A critique of some new guanxi scholarship. The China Quarterly 170: 459-476.

Yeung, H. 2002. Towards a relational economic geography: Old wine in new bottles? Paper presented at the 98th Annual Meeting of the AAG, March 19-23, 2002, Los Angles, CA.

. 2005. The firm as social networks: An organisational perspective. Growth and Change 36(3): $307-328$. 
254 GROWTH AND CHANGE, JUNE 2006

Zhu, Y. 2001. The management patterns of Taiwanese informatics investors in China. Taiwan Research Quarterly 74(4): 95-99 (in Chinese).

Zhuang, S.-Y., Z.-J. Chen, and B.-H. Chen. 2001. Taiwanese high technology firms cluster in YRD. Taipei, Taiwan: Global View Publisher (in Chinese). 